\title{
Renewable Energy Investment for Middle and Upper Class Housing Sector in Indonesia: Investigating the Scope for a Change in Policy
}

\author{
Tony K. Hariadi ${ }^{* 1}$, Milou Derks ${ }^{2}$, Agus Jamal ${ }^{1}$, Slamet Riyadi ${ }^{3}$ \\ ${ }^{1}$ Department of Electrical Engineering, Faculty of Engineering, Universitas Muhammadiyah Yogyakarta \\ Jalan Brawijaya, Geblangan, Tamantirto, Kasihan, Bantul 55183, Telp (0274) 387656 \\ ${ }^{2}$ Technology for Global Development, University of Technology Eindhoven (TU/e) \\ Eindhoven, the Netherlands \\ ${ }^{3}$ Department of Information Technology, Faculty of Engineering, Universitas Muhammadiyah Yogyakarta \\ Jalan Brawijaya, Geblangan, Tamantirto, Kasihan, Bantul 55183, Telp (0274) 387656
}

\begin{abstract}
The household sector plays an important role in the energy demand in Indonesia. Households consume more than 50\% of total energy in many major cities in Indonesia and account for 34\% of the total energy demand. The main share of capital allocation and attention, however, has gone to rural electrification programs over the past years with mixed results, due to an abundance of problems during the operation phase. We propose that government attention and capital should be broadened to policy development for solar home systems for urban areas. The problems that are encountered by rural electrification projects are mainly due to a lack of resources and unclear task allocation between involved parties and difficulties of addressing problems in remote environments. These risks are insignificant in urban areas where maintenance services are available and where solar home systems can be commercially interesting for higher income consumers without the need for subsidy. By means of a cost benefit analysis, this paper shows that solar home systems can be commercially interesting for households in urban areas. Different investment scenarios were worked out with systems costing 5\%, $10 \%$, and $15 \%$ of the total average house price. The analysis indicates that the policy is feasible when solar systems are coupled to the grid but not for off-grid systems. This is because the battery leads to high investment and maintenance cost. From a government point of view, developing policy towards renewable energy usage in urban households could help to reach national electrification and environmental targets without extra capital allocation as well as relieve pressure on the already overburdened state electricity company, the PLN.
\end{abstract}

Keywords: Energy policy, solar energy, renewable energy policy, Yogyakarta

\section{Introduction}

Indonesia has experienced a stable economic growth rate of roughly 5-6\% over the past years, this together with the growing population and the electrification ratio causes the energy demand to increase with about $7 \%$ per year. Expectations are that the electricity demand will triple between 2010 and 2030 if growth continues at this rate (Tharakan,
2015). This together with Indonesia's high vulnerability for the negative effects of climate change, and to increase Indonesia's energy security, stresses the importance of increasing the share of renewables in Indonesia's energy mix (Erahman, 2016) (Case, 2007). Investment capital is lacking at the National Energy Company (Perusahaan Listrik Negara $=$ PLN), Indonesia's state-owned electricity company which accounts for $97 \%$ of all household connections (Asian Development Bank 2016), due 
to low, universal electricity prices set by the government, the Asian financial crisis, customer debts, electricity theft and bad choices in power plant selection (Asian Develoment Bank, 2016) (Damuri 2012). This results in a lack of investment in power production, maintenance and strengthening of the distribution and transmission network.

Renewable energy projects in Indonesia, initiated by the government, the PLN or the private sector, have focused on two main areas: rural electrification and power plant construction. In both areas projects have run into problems that have led to more modest results than expected. Rural electrification projects have experienced problems with financing mechanisms which only include installation costs and ignore maintenance and operation costs, lack of capacity and knowledge among local communities, and poor project evaluation and communication issues.

Power plant construction projects are often delayed due to financing problems and problems with permits (Budiarto, 2013). Furthermore, rules and regulations make it extremely difficult for Independent Power Producers (IPPs) to invest in renewable power plants (PwC, 2013). Almost all government funding and attention is going to these two areas. But there is one area, which has been largely ignored and could help to substantially increase the fraction of renewable energy sources in the energy mix and increase electricity supply in line with growing demand: the urban residential building sector.

The urban residential building sector poses large potential for the use of renewable energy. Currently only households in rural electrification programs are considered, but the renewable energy potential of the building sector is so much larger. Allocating part of the budget of new residential construction to renewable energy could greatly increase the share of renewables in the energy mix and release some of the pressure on PLN to keep up with the growing energy demand. It could also relieve the pressure on the electricity network, which is already at its full capacity. In this sector we propose that part of government funding and attention should go to the development of policy directives for renewable energy use in the urban residential building sector. Since the energy consumption in buildings accounts for $34 \%$ of the total energy consumption, this could also greatly contribute to reaching Indonesia's renewable energy targets, which are to reach $23 \%$ of renewable energy in the share by 2025 and $31 \%$ by 2030 (IRENA, 2017). The economic growth rate results in a growing middle and upper class, this underscores the importance of renewable energy usage in buildings.

Indonesia has been developing policy to deploy renewable energy in rural communities for quite some time now (Mailoa, 2016). However there is no policy that states clearly how the household sector can integrate renewable energy in their home. The only policy on a national level for households is about energy reduction and energy efficiency. Also in Europe, the policy for the household sector is mainly on increasing their efficiency in energy consumption, rather than on producing the necessary energy on a household level. (Bosseboeuf, 2015) (Oxera Consulting, 2006).

The main reason why many renewable energy projects in rural areas have failed has been a lack of attention and resources for operation and maintenance. There has been no clear responsibility and task allocation for who is responsible for the costs of operation and maintenance and financial feasibility studies conducted prior to the construction of the projects do not take into account realistic scenarios of common system failures, and how the maintenance and repair costs during the operation phase could be covered.

Since urban areas are dominated by a higherincome population, who can also benefit from income from their own electricity generation through grid feed in, the risk of project failure due to a lack of financial means for operation and maintenance is much reduced. Furthermore, since most support centers are located in the city center, component replacement and reparations will be easier and much faster to organise. This article will explore the potential of the use of solar home systems in the residential household sector in Yogyakarta city, where energy consumption in this sector is more than $50 \%$. The targeted community is the upper-class community. Feasibility studies with various scenarios are considered and simulated to predict the energy savings made by allocating 5,10 or $15 \%$ of the house construction budget for a new construction of a renewable energy system.

\section{Methods}

Developing law and policy to promote renewable energy use in the building sector, will lead to $\mathrm{CO} 2$ 
emission reduction, alleviation of pressure on the PLN network and a decrease in the overall energy cost for the consumers. This is because the primary resource of many renewable energy sources is free, and although the upfront costs are high, the availability of free primary resources will lower the overall energy cost throughout the life cycle of the renewable energy installation. The high upfront costs and the inadequate financing opportunities for renewable energy projects in the absence of allocation of sufficient resources by local banks for this purpose, are the reasons why only the upper class is considered in this research paper. However, with proper funding mechanisms for the relatively high upfront costs, the scope of the analysis can be extended to the entire residential building sector.

Energy provision by solar panels is used as the main energy source in the proposed policy due to the longlife cycle and abundant source of solar radiation. A research on energy alternatives in Indonesia indicated that solar energy is the third best energy resources after hydro and geothermal, while the first two were not feasible for individual usage in buildings (Tasri, 2014). Energy from solar could also be combined with other sources, this could be and added value for ay household that will adopt this system (Nugroho et.al, 2017).

This paper assesses the potential financial feasibility of investing part of their housing construction budget in a solar installation. Three scenarios are considered. The effect on financial savings of allocating 5,10 and 15 percent of the total construction budget towards renewable energy is considered. Secondary data was used for the analysis and was supplied by government office in Yogyakarta and the PLN.

Wealth is the most determining factor for household energy usage in Indonesia indicated by the use of air conditioners, tvs, refrigerators and computers (Hariadi, 2016). The average household energy consumption and resulting $\mathrm{CO} 2$ emissions increases rapidly when the overall wealth of the household increases. The location of the household also greatly contributes to the energy usage. Cooking and cooling account for roughly $2 / 3$ of total energy consumption in wealthy households, the remaining $1 / 3$ is used for the fridge, lighting, entertainment and to power appliances (Kubota, 2014). The electricity price depends on the customer class and can be found in table 1 . There are 3 customer categories R1 ,R2 and R3. People with very low installed capacity (450 VA and 900
VA), receive subsidy and pay according to a sliding scale. In this paper we will focus on wealthy customers and therefore limit ourselves to customer group R3.

TABLE 1

Pln Electricity Prices Per Customer Category

\begin{tabular}{lll}
\hline $\begin{array}{l}\text { Tariff } \\
\text { Category }\end{array}$ & Power connected VA & Cost per kWh \\
\hline R1 & 450 VA & $0-30 \mathrm{kWh} \rightarrow$ IDR169 \\
& & $30-60 \mathrm{kWh} \rightarrow$ IDR360 \\
& $>60 \mathrm{kWh} \rightarrow$ DR405 \\
R1 & 900 VA & $0-30 \mathrm{kWh} \rightarrow$ IDR169 \\
& & $30-60 \mathrm{kWh} \rightarrow$ IDR 360 \\
& & $>60 \mathrm{kWh} \rightarrow$ IDR 600 \\
R1 & 1300-2200 VA & IDR 1364.86 \\
R2 & 3500-5500VA & IDR 1364.86 \\
R3 & 6600 VA and above & IDR 1364.86 \\
\hline
\end{tabular}

Households can choose to stay connected to the PLN grid, or switch to a completely independent off-grid system. If the household chooses to stay connected to the PLN grid, a kWh meter will be installed. Excess energy will not go to waste and will be fed back into the electricity grid. When the solar panels cannot satisfy the household's electricity consumption, electricity will be used from the grid. The electricity received by the PLN will be offset by the electricity that customers consume from the PLN. If the amount of electricity received by the PLN is bigger than the amount delivered to the household by the PLN, the PLN will give the household $\mathrm{kWh}$-credits which can be used in the upcoming months. According to Ministry Regulation no 27/2017, the customer will need to pay the fee for staying connected to the PLN. The household can also choose to be completely independent from the PLN. In this case batteries are necessary to guarantee electricity supply, during nights and cloudy days. The advantage for the customer of fully off-grid is that no connection fee to the PLN needs to be paid. Promoting fully off-grid systems will greatly benefit the PLN because it will relieve the already overburdened electricity grid. On-grid systems can also help relieve the burden on the PLN by producing energy which leads to a decrease in the energy the PLN needs to produce; it will also help to reach their renewable energy targets.

Data in this paper were supported by the Department of Energy and Mineral Resources, PLN and Department of Statisics, Daerah Istimewa Yogyakarta. Data was analized to calculate the cash flow and payback period. Economic analysis, was quite useful to calculate cost and benefit for this 
type of project (Buluş, 2011). Estimation on the increase of housing was also calculated using linear regression to indicate the increasing demand of energy.

\section{Estimations}

For this study the annual energy consumption data per household per customer class from the PLN was used. In 2016 the annual consumption of R3 Prepaid customer class was 4.815.088kWh (PLN, 2017). Since there were 581 households in this class, the average annual household consumptions were $8287,587 \mathrm{kWh}$. To be $100 \%$ independent of the grid the solar PV system should therefore deliver $22.28 \mathrm{kWh}$ daily. To account for differences in peak hour consumption and to guarantee security of supply $25 \%$ extra capacity should be installed. This results in a PV system that should roughly deliver $28 \mathrm{kWh}$ daily. Yogyakarta Province receives around 7 sun peak hours per day, this means that the necessary $28 \mathrm{kWh}$ needs to be produced per day, while average solar radiation intensity in Indonesia is $4.8 \mathrm{kWh} / \mathrm{m}^{2} / \mathrm{d}$ (Setiawan, 2017). The system should be able to deliver 4000 Watt, for a fully independent system. The number of batteries for such a system can be calculated by multiplying the daily watt-hour consumption with the number of consecutive days the batteries need to be able to deliver electricity without use of the solar panels. This number is then multiplied by 2 to account for the depth of charge (batteries should never be fully discharged because this results in rapid battery deterioration) and divided by the voltage of the battery and the capacity in Ah of the battery to get the number of batteries necessary. Battery calculation is as follows:

$$
\begin{aligned}
\Sigma_{\text {batt }}= & \frac{\text { Wh } \times \text { Days } \times \text { Depth Charge }}{\text { V x Batt Capacity }(\mathrm{Ah})} \\
\Sigma_{\text {batt }}= & \frac{28.000 \mathrm{Wh} \times 2 \times 2}{12 \times 40}
\end{aligned}
$$

Prices used for this calculation are:

TABLE 2

Prices of Solar PANels, InVERTERs, AND BATteries (SOURCE: LOCAL VENDOR, 2017)

Solar Panel $80 \mathrm{Wp}=75 \quad$ IDR 1.100 .000

$\mathrm{kWh}$ per year

Inverter 500 Watt

IDR 350.000

Inverter $1000 \mathrm{Watt}$

IDR 500.000

Battery $40 \mathrm{Ah}$

IDR 1.000 .000
Number of solar panels needed:

$$
\begin{aligned}
& \sum_{\mathrm{pv}}=\frac{\text { Average annual consumption }}{\mathrm{kWh}} \\
& \sum_{\mathrm{pv}}=\frac{8287,59}{75} \\
& =111 \text { solar panels }
\end{aligned}
$$

This will result in the total system price:

Total Price $=\left(\sum_{\mathrm{pv}} \mathrm{x}\right.$ IDR 1.100.000 $)$

$$
\begin{gathered}
+\left(\sum_{\text {batt }} \mathrm{X} \text { IDR 1.000.000 }\right) \\
+\left(\sum_{\text {inverter }} \mathrm{X} \text { IDR 500.000 }\right) \\
=\text { IDR } 346.000 .000
\end{gathered}
$$

to make an average R3 household $100 \%$ grid independent. This is however more than half of what most R3 customers pay for their entire house and therefore it will not be feasible for most R3 households. This is why we will now consider options in which 5\%, $10 \%$ and $15 \%$ of the total budget is used for a solar home system. Two options were considered; one in which batteries are used to make the system partially independent and one option in which batteries are not used but the network is used as a buffer. The housing price used in this simulation is 500 million, since this price will draw the line between the low and high-income community.

\section{Total Predicted Energy Savings}

The number of households in the R3 customer class has been rising over the past decade and will continue to rise further. The number of households in the R3 customer class in Yogyakarta since 2010 can be seen in figure 1 .

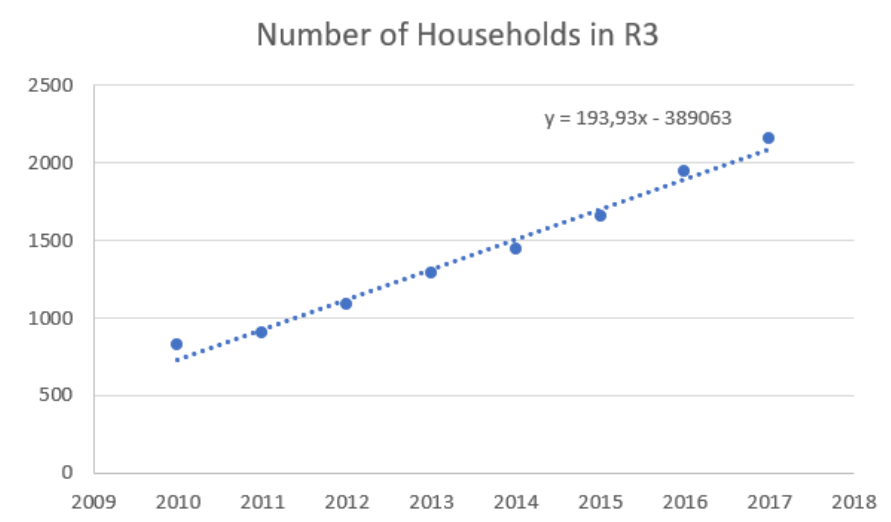

Fig. 1. Households in R3 Customer Class

From this we can conclude that the number of customers in the R3 household category is increasing with roughly 194 households every year., Other area in Indonesia also indicate an increase in this category. 


\section{Off-Grid System}

For the off-grid system the input for simulating the three different scenarios can be found in table 3 .

TABLE 3

DATA INPUT FOR OFF-GRID ESTIMATION

\begin{tabular}{llllll}
\hline & $5 \%$ of budget & $\begin{array}{l}10 \% \\
\text { budget }\end{array}$ & of & $\begin{array}{l}15 \% \\
\text { budget }\end{array}$ & of \\
\hline Initial & Cost & 25.250 .000 & 49.050 .000 & 75.300 .000
\end{tabular}

(IDR)

Number of

Solar Cells

Number of 1

Inverters

Number of 15

Batteries

Lifetime

Solar Panel

Lifetime

Inverter

Lifetime

Battery

Price per

$\mathrm{kWh}$

Annual

Solar Cell

Production

Annual

7612,59

17

26

Procuremen

$t$ from PLN

Discount

25 years

25 years

5 years

5 years

5 years

5 years

5 years

5 years

IDR 1364,86

IDR 1364,86

1275

1950

Rate [9]

The high costs of the batteries and their short lifetime make this solution unfeasible with the current relatively low electricity prices. This is because the savings that are made every year because of the use of electricity produced by the household system, are low compared to the high battery replacement cost. The electricity that cannot be produced by the solar home systems still needs to be bought from the PLN. The annual energy procurement for the three scenarios and a reference case in which no solar home systems are installed can be found in figure 2 .

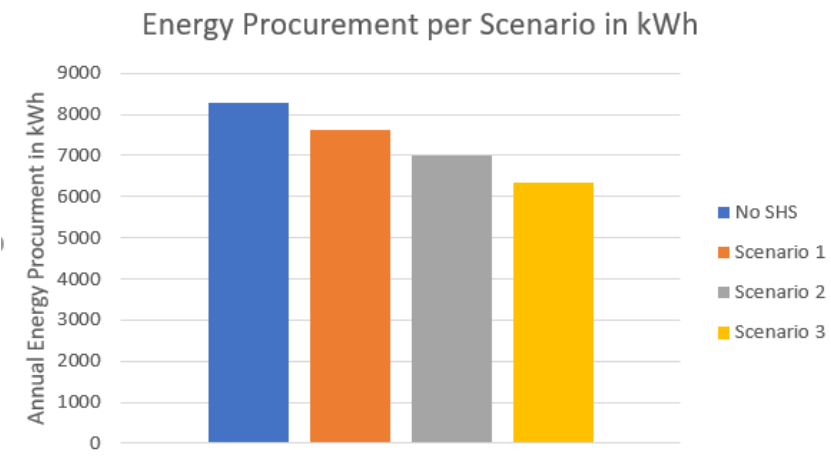

Fig. 2. Annual PLN Energy Procurement per Scenario

The cashflows throughout the lifetime of the solar home system can be seen in figure 3 .

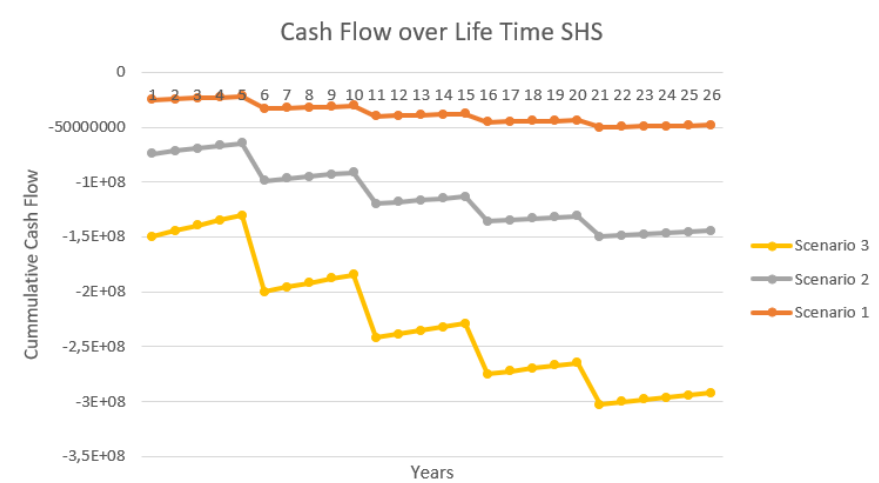

Fig. 3. Cumulative Cash Flows during Lifetime of SHS

The decreasing lines show clearly that the price of the battery replacement every five years outweighs the ongrid energy savings every year, making the off-grid scenario not financially feasible with the current low electricity prices, lack of subsidy and high battery prices.

\section{On-Grid System}

For the on-grid system the input for estimating the three different scenarios can be found in table 4 .

TABLE 4

DATA INPUT FOR ESTIMATION OF ON-GRID SCENARIOS

\begin{tabular}{|c|c|c|c|}
\hline & $5 \%$ of budget & $\begin{array}{l}10 \% \text { of } \\
\text { budget }\end{array}$ & $\begin{array}{l}15 \% \text { of } \\
\text { budget }\end{array}$ \\
\hline $\begin{array}{ll}\text { Initial } & \text { Cost } \\
\text { (IDR) } & \end{array}$ & 24.900 .000 & 49.450 .000 & 74.000 .000 \\
\hline $\begin{array}{l}\text { Number of } \\
\text { Solar Cells }\end{array}$ & 22 & 44 & 66 \\
\hline $\begin{array}{l}\text { Number of } \\
\text { Inverters }\end{array}$ & 2 & 3 & 4 \\
\hline $\begin{array}{l}\text { Lifetime } \\
\text { Solar Panel }\end{array}$ & 25 & 25 & 25 \\
\hline $\begin{array}{l}\text { Lifetime } \\
\text { Inverter }\end{array}$ & 5 & 5 & 5 \\
\hline $\begin{array}{l}\text { Price per } \\
\text { kWh (IDR) }\end{array}$ & 1364,86 & 1364,86 & 1364,86 \\
\hline $\begin{array}{l}\text { Annual } \\
\text { Solar Cell } \\
\text { Production } \\
\text { in kWh }\end{array}$ & 1650 & 3300 & 4950 \\
\hline $\begin{array}{l}\text { Annual } \\
\text { Procurement } \\
\text { from PLN in } \\
\mathrm{kWh}\end{array}$ & 6637,59 & 4987,59 & 3337,59 \\
\hline $\begin{array}{l}\text { Discount } \\
\text { Rate [9] }\end{array}$ & $4 \%$ & $4 \%$ & $4 \%$ \\
\hline
\end{tabular}

Since a large part of the capital does not have to be spent on the battery, alot more solar panels can be acquired. In all three scenarios, more than twice as many solar panels can be bought from the same budget. The electricity that cannot be produced by the solar home systems has to be bought from the PLN. The annual energy procurement for the three scenarios and a reference case in which no solar home systems are installed can be found in figure 4 . 


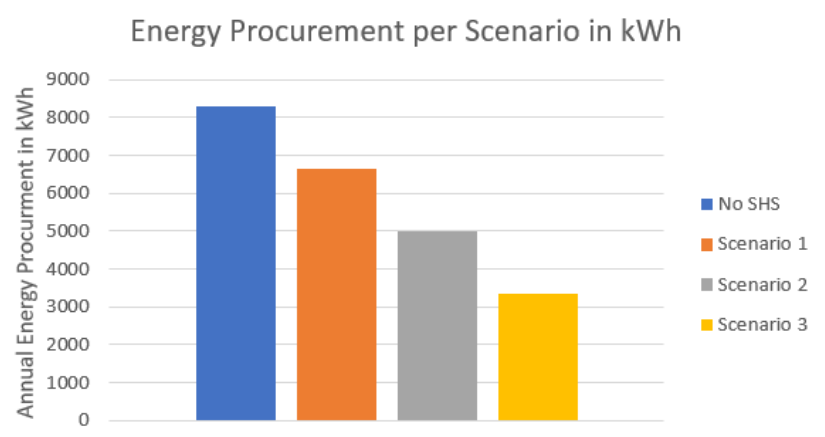

Fig. 4. Annual Energy PLN Procurement per Scenario

The cashflows throughout the lifetime of the solar panel can be seen in figure 5 .

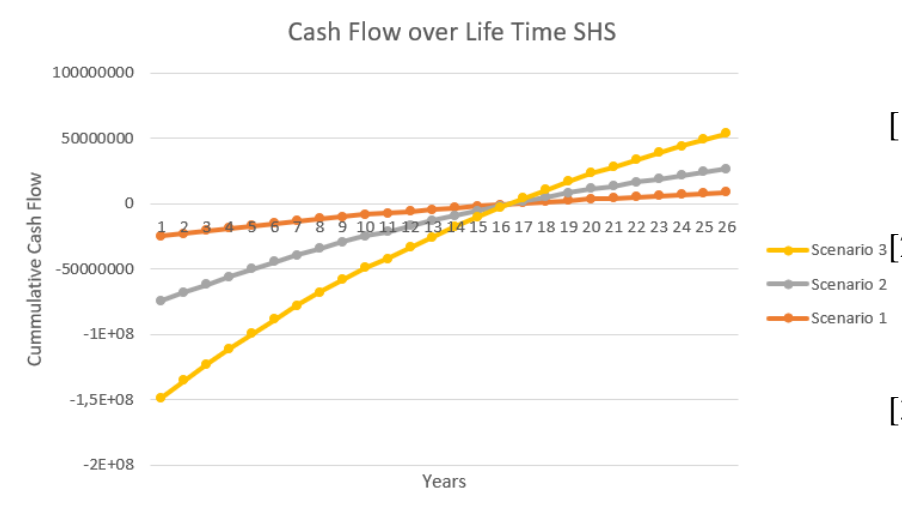

Fig. 5. Cumulative Cashflow over Lifetime of SHS

All three scenarios result in a positive cashflow after 16 years. This means the payback time of the system is 16 years. After the whole lifecycle of 25 years, scenario 1 has resulted in a saving of IDR 8.6 million, scenario 2 in IDR 17.9 million and scenario 3 in IDR 27.3. And since the government is planning to raise electricity prices in the future, the savings will be even higher than with this modest prediction.

\section{Conclusions}

To increase the share of renewables in Indonesia's energy mix and to relieve pressure on the national electricity provider PLN which has trouble keeping up with the growing energy demand, solar home systems can be a great opportunity for household customers. In this research the potential of both on- and off-grid systems were analyzed in an urban setting. In an urban environment, resource and knowledge constraints for ensuring adequate repair and maintenance as exist in remote rural areas are no major issue. Moreover, households in urban areas can make use of the main grid as a back-up energy source, while they can ngalso generate income by sell their domestically produced energy surplus to the grid. The target group was R3 household customers since this is the wealthiest group and the high upfront costs are most likely easier to deal with for this group.

When allocating 5,10 or $15 \%$ of the total house construction budget with proper financing opportunities and implementation of law and policy to promote solar home systems for household customers, this investment opportunity could greatly benefit both customers and the PLN, as well as increase the share of renewables in the energy mix while contributing to Indonesia's energy security. Furthermore, the potential of solar energy for household customers could be much larger than investigated in this paper. With proper financing mechanisms, households that already own a house can also acquire a solar home system and produce their own electricity, and the arrangement could also be brought within reach of middle-income households.

\section{References}

[1] Abdulkadir Buluş, N. T. (2011). Energy Efficiency and Rebound Effect: Does Energy Efficiency Save Energy? Energy and Power Engineering , 355-360.

[2] Adek Tasri, A. S. (2014). Selection among renewable energy alternatives based on a fuzzy analytic hierarchy process in Indonesia. Sustainable Energy Technologies and Assessments , 7, 34-44.

[3] Aiman Setiawan, E. A. (2017). Optimization of a Photovoltaic Power Plant in Indonesia with Proper Tilt Angle and Photovoltaic Type using a System Advisor Model. International Journal of Technology, 539-548.

[4] Asian Develoment Bank. (2016). Achieving Universal Electricity Access in Indonesia. Metro Manila: Asian Development Bank.

[5] Auke Hoekstra, M. S. (2017). Creating Agent-Based Energy Transition Management Models That Can Uncover Profitable Pathways to Climate Change Mitigation. Complexity, 2017, 23.

[6] Bisnis, K. (2017, Desember 12). BPK Temukan Proyek Energi Terbarukan Rp 1,17 T Mangkrak Sejak $2011 \quad$ Read more at https://kumparan.com/@kumparanbisnis/jurusesdm-cegah-proyek-proyek-energi-terbarukanmangkrak-lagi\#Zwwkfb2YIcB7pU1q.99. Retrieved from www.kumparan.com: https://kumparan.com/@ kumparanbisnis/bpktemukan-proyek-energi-terbarukan-rp-1-17-tmangkrak-sejak-2011?ref=body\&type=mbcjugal

[7] Bosseboeuf, D. (2015). Energy Efficiency Trends and Policies in the Household and Tertiary Sectors An Analysis Based on the ODYSSEE and MURE Databases . Inteligent Energy Europe Programme, European Union. Odyssee-Mure.

[8] Febrilian Erahman, Q. \&. (2016). An Assesment of Indonesia's Energy Security Index and Comparison with Seventy Countries. Energy, 364-378. 
[9] Hariadi, Tony K. ,P. P. (2017). Energy Saving Technology Analysis for Commercial, Industrial, Social, and Public Sectors to Support Regional Energy Policy: Case Study in Daerah Istimewa Yogyakarta. International Journal of Applied Engineering Research , 11933-11940.

[10] Hermawan Nugroho, Siaw Fei-Lu \& Firmansyah (2017) Developing renewable energy in developing countries: A lesson from Indonesia, Energy Sources, Part B: Economics, Planning, and Policy, 12:4, 318325, DOI: $10.1080 / 15567249.2015 .1072599$

[11] Hermawati W., P. H. (2016). Influential Factors of Evidence-Based Energy Policy-making: Government Regulation on Targeting Renewable Energy in Indonesia. Journal of STI Policy and Management , 1 (1), 59-73.

[12] IRENA. (2017). REthinking Energy 2017: Accelerating the Global Energy Transformation. Abu Dhabi: International Energy Agency.

[13] Jonathan P. Mailoa, R. P. (2016, January 25). Bringing renewable energy to life i Indonesia: Solar and beyond. The Jakarta Post , pp. 1-6.

[14] Michael Case, F. A. (2007, November 28). Climate Change in Indonesia, Implications for Human and Nature. Retrieved from www.wwfblogs.org: www.wwfblogs.org/climate/sites/default/files/WWF Binaryitem7664.pdf

[15] NV. (2016, July 29). Proyek PLTS di Baturinggit Mangkrak. Retrieved from Nusabali.com: http://www.nusabali.com/berita/6477/proyek-pltsdi-baturinggit-mangkrak

[16] Oxera Consulting. (2006). Policies for energy efficiency in the UK household sector. Oxera Consulting.

[17] PLN. (2017). Format Data PLN DIY 2010-2017. Yogyakarta: PLN.

[18] PwC. (2013). Investment and Taxation Guide 2nd Edition Featuring an additional chapter on renewable energy. PwC Indonesia.

[19] Rachmawan Budiarto, M. K. (2013). Sustainability Challenge for Small Scale Renewable Energy Use in Yogyakarta. The 3rd International Conference on Sustainable Future for Human Security (SUSTAIN 2012) (pp. 513-518). Elsevier.

[20] Saepudin, T. (2018). Development of electricity program, electrificaty ratio with human development index in West Java Provice, Indonesia. International JOurnals of Energy Economics and Policy , 8 (1), 227-230.

[21] Setiartiti, L. (2018). Renewable Energy Utilizing for Clean Energy Development . International Journal of Energy Economics and Policy , 8 (1), 212-219.

[22] Sukoco. (2017, September 19). PLTS Bantuan Kementerian Desa di Nunukan Mangkrak Sejak Dibangun 2013. Kompas , pp. 1-6.
[23] Suyash Jolly, R. R. (2012). Upscaling of business model experiments in off-grid PV solar energy in India. Sustainability Science, 7 (2), 199-212.

[24] Tetsu Kubota, U. S. (2014). A Comparative Analysis of Household Energy Consumption in Jakarta and Bandung. 30th International Plea Conference. Ahmedabad: CEPT University.

[25] Tharakan, P. (2015). Summary of Indonesia,s Energy Sector Assesment. Metro Manila: Asia Development Bank.

[26] Tony K. Hariadi, P. J. (2016). Energy Efficiency and Policy Analysis for Household in DI Yogyakarta (Yogyakarta Special Region) Indonesia. International Journal on Advance Science Engineering Information Technology, 329-333. 